\title{
RAPID EVALUATION OF GERMINABILITY OF PRIMED CHINA ASTER (CALLISTEPHUS CHINENSIS NESS.) SEEDS WITH PHYSIOLOGICAL AND BIOCHEMICAL MARKERS
}

\author{
Bogumiła BADEK ${ }^{1 *}$, Zdzisława ROMANOWSKA-DUDA ${ }^{2}$, Mieczysław GRZESIK ${ }^{1}$, \\ Bert van DUIJN ${ }^{3,4}$ \\ ${ }^{1}$ Research Institute of Horticulture, ul. Konstytucji 3 Maja 1/3, 96-100 Skierniewice, Poland \\ ${ }^{2}$ University of Lodz, Department of Ecophysiology and Plant Development, \\ Banacha 12/16, 90-232 Lodz, Poland \\ ${ }^{3}$ Fytagoras, Sylvius Laboratory, Sylviusweg 72, 2333 BE Leiden, the Netherlands \\ ${ }^{4}$ Institute of Biology Leiden, Leiden University, Sylviusweg 72, 2333 BE Leiden, the Netherlands
}

Received: August 20, 2014; Accepted: October 3, 2014

\begin{abstract}
The correlation between the sowing value of primed China aster seeds represented by germination percentage (GP), mean germination time (MGT), germination uniformity expressed as the time between $25 \%$ and $75 \%$ of germinated seeds $\left(\mathrm{T}_{75-25}\right)$ and some selected physiological characteristics - total activity of dehydrogenases (TAD), activity of catalase (AC), activity of cell cycle (ACC) and electrolyte leakage (EL) has been analysed in order to find useful markers of biological quality of seeds. To achieve this objective, analyses of effects of three methods of water supply to seeds viz. - hydroconditioning by soaking in excessive amount of water (M1), hydroconditioning by soaking in limited amount of water (M2) or hydroconditioning by contact with solid carrier of water - matriconditioning (M3), three levels (30.0, 35.0 and $40.0 \%$ ) of seed moisture content (m.c.) and three incubation periods (1, 8 and 10 days) during priming and hence their influence on germination properties (GP, MGT, $\mathrm{T}_{75-25}$ ) in comparison with TAD, AC, ACC and EL were determined. The results showed that MGT and $\mathrm{T}_{75-25}$ were correlated with TAD, AC, ACC and EL, irrespective of their priming method and sowing value. Therefore, all the investigated physiological/biochemical parameters of seed quality can be used as markers of germinability and sowing value reached by primed China aster seeds. The results also proved that, irrespective of the water supply method applied, hydration of seeds up to $37.5 \%$ m.c., and their incubation at $20{ }^{\circ} \mathrm{C}$ for 8 days, followed by drying to their initial moisture content, increased to the greatest extent the speed and uniformity of seed germination and their physiological activity.
\end{abstract}

Key words: enzymes activity, electrolyte leakage, seed germination, physiological markers, priming of seeds

\section{INTRODUCTION}

Mass production of China aster (Callistephus chinensis Nees.) is often hampered by the poor quality of seeds, which is mostly connected with unfavourable weather conditions during seed development and maturation (Yu-jie et al. 2009). To improve the seed quality, several priming techniques, i.e. hydropriming, osmopriming, solid matrix prim- ing can be used. Priming includes pre-sowing of seeds at controlled hydration followed by their incubation, which results in pre-germinative metabolic activation to the degree not allowing the radicle to protrude through the seed coat (Nascimento \& Aragao 2004; Dursun \& Ekinci 2010). In order to evaluate seed ability for germination, different methods were applied, as automatic evaluation of germination based on the automated germination 
scoring system (the image analysis) (Joosen et al. 2010) or evaluation of glowing of substances emitted by seeds such as sinapine in cabbage (Taylor et al. 1993). Also, for rapid evaluation of seed quality, application of biochemical and physiological markers is suggested. Here, an important problem is a shortage of reliable and simple physiological markers, which would be equivalent, alternative or faster than germination test examining percentage and vigour of seeds that can predict after-sowing seed performance and proper seedlings development. Therefore, there is a strong interest in identifying additional physiological markers of seed sowing quality, which could give important information about their metabolic status, determining germinability (Job et al. 2000; Bakht et al. 2011). Some physiological events, such as changes in DNA amount and replication, activity of some enzymes and cytomembrane permeability (Bewley \& Black 1994; Gallardo et al. 2001; Badek et al. 2006, 2007; Grzesik \& Romanowska-Duda 2009, 2014), cellcycle activity (Śliwińska 2009), late embryogenesis abundant proteins (LEA) (Job et al. 1997; Capron et al. 2000), $\beta$-tubulin (de Castro et al. 1995) were observed in seeds exhibiting different germinability. However, the published data did not provide information indicating the exact correlation between the changing parameters of seed germinability and the physiological activities, which can be proposed as useful markers of seed sowing quality. Indication of close correlation between physiological processes and seed germination can mean a further step in the process to develop markers of the seed germination.

The aim of this study was to evaluate the correlation between a sowing value of differently primed China aster seeds through germination percentage (GP) - number of the germinated seeds, mean time of germination (MGT), germination uniformity - expressed as the time between $25 \%$ and $75 \%$ of germinated seeds $\left(\mathrm{T}_{75-25}\right)$ and the selected physiological events through total activity of dehydrogenases (TAD), activity of catalase (AC), activity of cell cycle (ACC) and electrolyte leakage (EL), in order to find useful markers of biological quality of seeds. To show the usefulness of the studied markers in evaluation of differently primed and germinated seeds, the study was performed on seeds hy- drated with three methods up to different moisture content and incubated from one to 10 days.

\section{MATERIAL AND METHODS}

Experiments were conducted on seeds of China aster (Callistephus chinensis Ness.) 'Jolanta' obtained from seed company PNOS Ożarów Mazowiecki, Poland. The Calflo ${ }^{\circledR}$ (a synthetic calcium and magnesium silicate were used here as solid moist carrier) was purchased from Celite Corporation, Lompoc, CA 93438, USA. Untreated seeds served as the control batch. The moisture content of the untreated seeds was $8.2 \%$.

\section{Seed conditioning}

Three methods of seed priming were used in the experiment:

1. Hydroconditioning by soaking in excessive amount of water (M1).

Seeds were soaked in an excessive amount of water, at the ratio of seeds to water $(\mathrm{w}: \mathrm{w}) 1: 3$, by placing the seeds in glass bottles filled with aerated distilled water, for 30,60 and $120 \mathrm{~min}$ at $20^{\circ} \mathrm{C}$, to obtain a seed moisture content (m.c.) of 30.0, 37.5 and $40.0 \%$, respectively. After hydration, the seeds were surface dried between sheets of filter paper for $5 \mathrm{~s}$, and subsequently incubated for 1,8 and 10 days in daily aerated air-tight glass bottles at $20{ }^{\circ} \mathrm{C}$. Above treatments were chosen for these experiment on the basis of earlier results (Badek et al. 2006, 2007).

2. Hydroconditioning by soaking in limited amount of water (M2).

Seeds were soaked in limited amounts of water, i.e. 320,480 and $560 \mathrm{ml}$ water per kilogram of seeds to obtain moisture content of $30.0,37.5$ and $40.0 \%$, respectively and then incubated for 1,8 and 10 days in daily aerated air-tight glass bottles at $20^{\circ} \mathrm{C}$.

3. Matriconditioning (M3).

Seeds were hydrated by contact with Calflo (the moist solid carrier) in limited amount of water and then incubated for 1,8 and 10 days at $20^{\circ} \mathrm{C}$ in airtight glass bottles. The ratio of seeds to Calflo was constant $(1.0: 0.4, \mathrm{w}: \mathrm{w})$ and the ratio of seeds to water varied $(1.0: 0.6,1.0: 1.2,1.0: 1.4 ; \mathrm{w}: \mathrm{w})$ to obtain moisture content of $30.0,37.5$ and $40.0 \%$, respectively. The matriconditioned seeds were aerate 
every day for a few seconds. After the incubation, the seeds were washed for $5 \mathrm{~s}$ with distilled water to remove Calflo residues from their surface.

After conditioning, all seeds were dried for 2 days on filter paper at $20{ }^{\circ} \mathrm{C}$ and $40.0 \%$ air relative humidity $(\mathrm{RH})$ for reaching the initial m.c. Then, the primed and dried seeds were subjected to evaluations of germination percentage (GP), mean germination time (MGT), uniformity of germination $\left(\mathrm{T}_{75-25}\right)$ and different physiological-biochemical parameters, such as total activity of dehydrogenase (TAD), activity of catalase (AC), activity of cell cycle (ACC) and electrolyte leakage (EL).

\section{Seed moisture content}

The moisture content (m.c.) of seeds was determined in two replications according to the ISTA procedure (ISTA 2011).

\section{Seed germination properties}

Seed germination was evaluated daily at temperatures of 5,20 and $35^{\circ} \mathrm{C}$. Three replications of 50 seeds each were sown in $9.0 \mathrm{~cm}$-diameter Petridishes on cotton wool moistened with $6.0 \mathrm{ml}$ of distilled water. Each seed was counted as germinated when its radical protruded through the seed coat.

Seed Calculator Version 3.0 software developed at the Plant Research International in Wageningen University (the Netherlands) was applied to calculate the mean germination time (MGT), germination uniformity $\left(\mathrm{T}_{75-25}\right)$ and the seeds germination percentage (GP).

\section{Total activity of dehydrogenases}

A procedure described by Górnik and Grzesik (2002) was used for the overall assessment of dehydrogenases activity in seeds. $0.2 \mathrm{~g}$ of seeds was placed in Eppendorf tubes, grounded and incubated in $1 \mathrm{ml}$ of $0.1 \mathrm{M}$ sodium phosphate buffer, $\mathrm{pH} 7.2$ containing $0.7 \%(\mathrm{w} / \mathrm{v})$ of $2,3,5$-triphenyl tetrazolium chloride (TTC) at $25{ }^{\circ} \mathrm{C}$ for $24 \mathrm{~h}$. Then, the seed samples were centrifuged $(5 \mathrm{~min} / 5000 \times \mathrm{g})$ and the pellet was extracted six times with $1 \mathrm{ml}$ of acetone. The content of formazan $\left(\mathrm{mg} \cdot \mathrm{g}\right.$ seeds $\left.\mathrm{s}^{-1}\right)$ was determined by means of comparing the absorption of tested extract from embryos and calibration solution. The absorption of the extract was measured at $480 \mathrm{~nm}$ using Spectrophotometer UVmini-1240 SHIMADZU.

\section{Activity of catalase}

Catalase activity was determined spectrophotometrically as previously described by Bailly et al. (1996), following $\mathrm{H}_{2} \mathrm{O}_{2}$ consumption at $240 \mathrm{~nm}$. The test was carried out in a total volume of $3 \mathrm{ml}$ of $50 \mathrm{mM}$ potassium phosphate buffer $(\mathrm{pH} 7.0)$ containing $37.5 \mathrm{mM}$ of $\mathrm{H}_{2} \mathrm{O}_{2}$ and $0.2 \mathrm{ml}$ of enzyme extract. The UVmini-1240 SHIMADZU and software for measuring kinetics (Kinetics Program Pack for UVmini-1240) were applied. The catalase activity was expressed as nanomoles of $\mathrm{H}_{2} \mathrm{O}_{2}$ decomposed per minute per gram of protein.

\section{Activity of the cell cycle}

Samples for cytometric analysis were prepared according to the method described by Śliwińska (2008). The evaluation was conducted using a flow cytometer (Partec CCA, Münster, Germany), with the application of the logarithmic scale. On the basis of the achieved results, a share of nuclei characteristic of different content of DNA and the $4 \mathrm{C} / 2 \mathrm{C}$ coefficient was calculated.

\section{Electrolyte leakage}

Leakage of electrolytes, being an indicator of membrane permeability, was measured according to Górnik and Grzesik (2002) with a current own modification. Thirty seeds, which were uniform in size and with no visual damage, were soaked in $3 \mathrm{ml}$ of deionised distilled water at $20{ }^{\circ} \mathrm{C}$ for $4 \mathrm{~h}$, followed by measuring the conductivity using CC-551-ELMETRON. Then, the samples were boiled at $100{ }^{\circ} \mathrm{C}$ for $12 \mathrm{~min}$ for measuring the maximal conductivity for each sample. The results were presented as percentage of the total electrolyte conductivity.

\section{Statistical analyses}

The experiment was conducted as a randomised complete design in three replications. The Duncan's multiple range tests were applied to compare the treatment means. The probability level chosen for significant difference was $\mathrm{p}<0.05$. Pearson's correlation coefficients ( $r$-values) were used to evaluate the relationship between China aster seed sowing value (GP, MGT, $\mathrm{T}_{75-25}$ ) and selected physiological events (TAD, AC, ACC, EC). A linear regression model was used for the analysis. Program 'STATISTICA version 10' was used to perform all statistical analyses. 


\section{RESULTS}

\section{Seed germination properties}

China aster seeds, conditioned by three different methods (M1, M2 and M3) were subjected to germination at 5,20 and $35^{\circ} \mathrm{C}$. The most pronounced differences in speed and uniformity of seed germination of the differently treated seeds were observed at the lowest temperature $\left(5^{\circ} \mathrm{C}\right)$, as compared to tests conducted at 20 and $35^{\circ} \mathrm{C}$ and those are presented in Table 1.

Positive effects of conditioning on the majority of germination parameters of China aster seeds were observed. The germination percentage of seeds moistened from $8.2 \%$ up to $30.0 \%$ and $37.5 \%$ and then incubated for 1 and 8 days was higher as compared with the control batch. Moistening of seeds up to $40 \%$ and incubated for one day caused a lower capability of germination (94.7-95.3\%). Seeds moistened up to $40 \%$ m.c. and incubated for 8 and 10 days started to germinate already at the end of incubation periods (Table 1).

Each method of priming significantly shortened the mean time of germination (MGT) and increased germination uniformity $\left(\mathrm{T}_{75-25}\right)$ as compared with untreated seeds. Moistening of seeds from $8.2 \%$ up to $37.5 \%$ m.c. and their subsequent incubation for 8 days proved to be most effective in terms of shortening time of germination, and increasing germination uniformity, irrespective of the applied method of conditioning. The MGT was reduced from 6.4 days (control) up to 1.4 days (M1), 1.3 days (M2) and 1.6 days (M3). The values of the ( $\left.\mathrm{T}_{75-25}\right)$ parameter for these seeds were reduced to 0.8 day (M1), 0.7 day (M2) and 0.8 day (M3), whereas for the control group the value was 1.4 days (Table 1 ).

Table 1. Germination percentage (GP), mean germination time (MGT) and time between 25 and $75 \%$ germination of $\mathrm{G}_{\max }\left(\mathrm{T}_{75-25}\right)$ at $5{ }^{\circ} \mathrm{C}$ of China aster seeds imbibed up to $30.0,37.5$ and $40.0 \%$ by soaking in excessive amount of water (M1), soaking in limited amount of water (M2) or matriconditioning (M3) and then incubated for 1,8 and 10 days at $20{ }^{\circ} \mathrm{C}$

\begin{tabular}{|c|c|c|c|c|c|c|c|c|c|}
\hline \multirow{3}{*}{$\begin{array}{c}\text { Moisture } \\
\text { content } \\
(\%)\end{array}$} & \multicolumn{3}{|c|}{ GP $(\%)$} & \multicolumn{3}{|c|}{ MGT (days) } & \multicolumn{3}{|c|}{$\mathrm{T}_{75-25}$ (days) } \\
\hline & \multicolumn{9}{|c|}{ Incubation time (days) } \\
\hline & 1 & 8 & 10 & 1 & 8 & 10 & 1 & 8 & 10 \\
\hline \multirow[t]{2}{*}{8.2 (control) } & $97.3_{\mathrm{c}}$ & $97.3_{\mathrm{c}}$ & $97.3_{\mathrm{c}}$ & $6.4_{a}$ & $6.4_{a}$ & $6.4_{a}$ & $1.4_{\mathrm{a}}$ & $1.4_{\mathrm{a}}$ & $1.4_{\mathrm{a}}$ \\
\hline & \multicolumn{9}{|c|}{ Soaking in excessive amount of water (v/v) $1: 3$ (M1) } \\
\hline 30.0 & $97.7 \mathrm{~b}$ & $98.7 \mathrm{a}$ & $93.3_{\mathrm{g}}$ & $4.6_{c}$ & $3.2 \mathrm{k}$ & $3.9 \mathrm{e}$ & $1.3 \mathrm{bc}$ & $0.9_{\mathrm{ij}}$ & $1.2 \mathrm{c-f}$ \\
\hline 37.5 & $97.7_{\mathrm{b}}$ & $98.7 \mathrm{a}$ & $91.3_{\mathrm{i}}$ & $3.06_{1}$ & $1.4_{\mathrm{o}}$ & $3.0_{11}$ & $1.1_{\mathrm{d}-\mathrm{g}}$ & $0.8 \mathrm{k}$ & $1.1 \mathrm{fgh}$ \\
\hline \multirow[t]{2}{*}{40.0} & $95.3_{\mathrm{d}}$ & $\mathrm{G}^{*}$ & $\mathrm{G}$ & $3.4_{\mathrm{ij}}$ & $\mathrm{G}$ & $\mathrm{G}$ & $1.2 \mathrm{~b}-\mathrm{e}$ & $\mathrm{G}$ & $\mathrm{G}$ \\
\hline & \multicolumn{9}{|c|}{ Soaking in limited amount of water (M2) } \\
\hline 30.0 & $98.0_{\mathrm{b}}$ & $98.7 \mathrm{a}$ & $94.0_{\mathrm{f}}$ & $4.3_{\mathrm{d}}$ & $2.8_{\mathrm{m}}$ & $3.7_{\mathrm{f}}$ & $1.2 \mathrm{bcd}$ & $0.8_{\mathrm{k}}$ & $1.2_{\mathrm{def}}$ \\
\hline 37.5 & $98.0_{\mathrm{b}}$ & $98.7 \mathrm{a}$ & $92.0_{\mathrm{h}}$ & $2.9_{\mathfrak{l}}$ & $1.3_{\mathrm{p}}$ & $2.9_{\mathrm{l}}$ & $1.1_{\mathrm{e}-\mathrm{h}}$ & $0.7_{1}$ & $1.0_{\mathrm{ghi}}$ \\
\hline \multirow[t]{2}{*}{40.0} & $95.3_{\mathrm{d}}$ & $\mathrm{G}$ & $\mathrm{G}$ & $3.2 \mathrm{k}$ & $\mathrm{G}$ & $\mathrm{G}$ & $1.2_{\mathrm{c}-\mathrm{f}}$ & $\mathrm{G}$ & $\mathrm{G}$ \\
\hline & \multicolumn{9}{|c|}{ Matriconditioning (M3) } \\
\hline 30.0 & $97.7_{\mathrm{b}}$ & $98.0_{\mathrm{b}}$ & $93 . \mathrm{g}_{\mathrm{g}}$ & $4.9 \mathrm{~b}$ & $3.6_{\mathrm{fg}}$ & $4.2_{\mathrm{d}}$ & $1.3 \mathrm{~b}$ & $1.0_{\mathrm{hi}}$ & $1.3 \mathrm{bc}$ \\
\hline 37.5 & $97.7_{\mathrm{b}}$ & $98.0_{\mathrm{b}}$ & $91.3_{\mathrm{i}}$ & $3.6_{\mathrm{gh}}$ & $1.6_{\mathrm{n}}$ & $3.3_{\mathrm{j}}$ & $1.2_{\mathrm{c}-\mathrm{f}}$ & $0.8_{\mathrm{k}}$ & $1.1_{\mathrm{d}-\mathrm{g}}$ \\
\hline 40.0 & $94.7_{\mathrm{e}}$ & $\mathrm{G}$ & $\mathrm{G}$ & $3.5_{\mathrm{hi}}$ & $\mathrm{G}$ & $\mathrm{G}$ & $1.2 \mathrm{bcd}$ & $\mathrm{G}$ & $\mathrm{G}$ \\
\hline
\end{tabular}

Means with the same letters for each trait are not significantly different at $p<0.05$ according to Duncan's multiple range test

* Seeds germinated already during incubation 
Table 2. Activity of catalase (AC) and total activity of dehydrogenase (TAD) in China aster seeds imbibed up to $30.0,37.5$ and $40.0 \%$ by soaking in excessive amount of water (M1), soaking in limited amount of water (M2) or matriconditioning (M3) and then incubated for 1,8 and 10 days at $20{ }^{\circ} \mathrm{C}$

\begin{tabular}{|c|c|c|c|c|c|c|}
\hline \multirow{3}{*}{$\begin{array}{c}\text { Moisture } \\
\text { content }(\%)\end{array}$} & \multicolumn{3}{|c|}{$\mathrm{AC}\left(\mathrm{nmol} \mathrm{H}_{2} \mathrm{O}_{2} \cdot \mathrm{min}^{-1} \cdot \mathrm{g}_{\text {protein }}{ }^{-1}\right)$} & \multicolumn{3}{|c|}{ TAD $\left(\mathrm{mg}\right.$ formazan $\left.\cdot \mathrm{g} \mathrm{seeds}^{-1}\right)$} \\
\hline & \multicolumn{6}{|c|}{ Incubation time (days) } \\
\hline & 1 & 8 & 10 & 1 & 8 & 10 \\
\hline \multirow[t]{2}{*}{8.2 (control) } & $0.045 \mathrm{n}$ & $0.045 \mathrm{n}$ & $0.045 \mathrm{n}$ & $0.35 \mathrm{n}$ & $0.35 \mathrm{n}$ & $0.35 \mathrm{n}$ \\
\hline & \multicolumn{6}{|c|}{ Soaking in excessive amount of water (v/v) $1: 3(\mathrm{M} 1)$} \\
\hline 30.0 & 0.0531 & $0.069 \mathrm{f}$ & $0.056 \mathrm{kl}$ & 0.441 & $0.56 \mathrm{~g}$ & $0.49 \mathrm{k}$ \\
\hline 37.5 & $0.066 \mathrm{~g}$ & $0.079 \mathrm{~b}$ & $0.069 \mathrm{f}$ & 0.59 ef & $0.67 \mathrm{~b}$ & $0.59 \mathrm{ef}$ \\
\hline \multirow[t]{2}{*}{40.0} & $0.062 \mathrm{ij}$ & $\mathrm{G}^{*}$ & $\mathrm{G}$ & $0.52 \mathrm{i}$ & $\mathrm{G}$ & $\mathrm{G}$ \\
\hline & \multicolumn{6}{|c|}{ Soaking in limited amounts of water (M2) } \\
\hline 30.0 & $0.057 \mathrm{k}$ & $0.073 \mathrm{~d}$ & $0.062 \mathrm{ij}$ & $0.49 \mathrm{k}$ & $0.61 \mathrm{~d}$ & $0.52 \mathrm{i}$ \\
\hline 37.5 & $0.069 \mathrm{f}$ & $0.082 \mathrm{a}$ & $0.071 \mathrm{e}$ & $0.59 \mathrm{e}$ & $0.70 \mathrm{a}$ & $0.61 \mathrm{~d}$ \\
\hline \multirow[t]{2}{*}{40.0} & $0.064 \mathrm{~h}$ & $\mathrm{G}$ & $\mathrm{G}$ & $0.55 \mathrm{~h}$ & $\mathrm{G}$ & $\mathrm{G}$ \\
\hline & \multicolumn{6}{|c|}{ Matriconditioning (M3) } \\
\hline 30.0 & $0.051 \mathrm{~m}$ & $0.065 \mathrm{~h}$ & 0.0561 & $0.42 \mathrm{~m}$ & $0.52 \mathrm{i}$ & 0.451 \\
\hline 35.0 & $0.063 \mathrm{hi}$ & $0.077 \mathrm{c}$ & $0.066 \mathrm{~g}$ & $0.54 \mathrm{~h}$ & $0.65 \mathrm{c}$ & $0.58 \mathrm{f}$ \\
\hline 40.0 & $0.062 \mathrm{j}$ & $\mathrm{G}$ & G & $0.50 \mathrm{j}$ & $\mathrm{G}$ & $\mathrm{G}$ \\
\hline
\end{tabular}

Means with the same letters for each trait are not significantly different at $\mathrm{p}<0.05$ according to the Duncan's multiple range test

* Seeds germinated already during incubation

\section{Activity of catalase}

The activity of catalase in the control seeds was $0.045 \mathrm{nmol} \mathrm{H}_{2} \mathrm{O}_{2} \cdot \mathrm{min}^{-1} \cdot \mathrm{g}$ protein ${ }^{-1}$, whereas in the seeds hydrated from $8.2 \%$ up to $30.0,37.5$ and $40.0 \%$, and subsequently incubated for 1,8 and 10 days was significantly higher than in the control batch. The highest activity of catalase was found in seeds moistened up to $37.5 \%$ and incubated for 8 days. These conditions resulted in increasing catalase activity up to 0.079 (M1), 0.082 (M2) and 0.077 (M3) nmol $\mathrm{H}_{2} \mathrm{O}_{2} \cdot \mathrm{min}^{-1} \cdot \mathrm{g} \mathrm{prot}^{-1}$ (Table 2).

\section{Total activity of dehydrogenases}

Total activity of dehydrogenases was higher in all primed China aster seeds in comparison with the untreated control. The total activity of dehydrogenase in the control seeds was $0.35 \mathrm{mg}$ formazan $\cdot$ g seeds $^{-1}$ (Table 2). In seeds hydrated from $8.2 \%$ up to $30.0,37.5$ and $40.0 \%$ and then incubated for 1,8 and 10 days, the total activity of dehydrogenase depended on the method of conditioning being highest at $37.5 \%$ and 8 days of incubation -
0.67 (M1), 0.70 (M2) and $0.65 \mathrm{mg}$ forma$\mathrm{zan} \cdot \mathrm{g} \mathrm{seeds}^{-1}(\mathrm{M} 3)$. The highest activity of dehydrogenase was found in seeds hydrated up to $37.5 \%$ m. c. and then incubated for 8 days (Table 2).

\section{Activity of cell cycle}

Contribution of $4 \mathrm{C}$ nuclei in radicle tips protruded from seeds of China aster conditioned by three methods is shown in Table 3. In the dry unprimed seeds, $97.05 \%$ of the nuclei emitted $2 \mathrm{C}$ signal, whereas in the seeds hydrated to $37.5 \%$ m.c. and then incubated for 8 days (M1) a frequency of $4 \mathrm{C}$ nuclei (G2 phase) increased from $2.95 \%$ to $4.74 \%$ (M1), in M2 to $4.91 \%$ and in M3 to $4.66 \%$ (Table 3).

\section{Electrolyte leakage}

The electrolyte leakage from control seeds (47.9\%) was significantly higher than from the primed seed. The amount of electrolyte leakage from seeds hydrated up to $37.5 \%$ m.c. and incubated for 8 days was reduced most significantly, i.e. down to $18.7 \%$ (M1), $16.8 \%$ (M2) and 20.3\% (M3) (Table 3). 
Table 3. Activity of cell cycle (ACC) and electrolyte leakage (EL) in China aster seeds imbibed up to 30.0, 37.5 and $40.0 \%$ by soaking in excessive amount of water (M1), soaking in limited amount of water (M2) or matriconditioning (M3) and then incubated for 1,8 and 10 days at $20{ }^{\circ} \mathrm{C}$. G - seeds germinated already during incubation

\begin{tabular}{|c|c|c|c|c|c|c|}
\hline \multirow{3}{*}{$\begin{array}{c}\text { Moisture } \\
\text { content }(\%)\end{array}$} & \multicolumn{3}{|c|}{ ACC (\% 4C signals) } & \multicolumn{3}{|c|}{ EL (\% total leakage) } \\
\hline & \multicolumn{6}{|c|}{ Incubation time (days) } \\
\hline & 1 & 8 & 10 & 1 & 8 & 10 \\
\hline \multirow[t]{2}{*}{8.2 (control) } & $2.95 \mathrm{n}$ & $2.95 \mathrm{n}$ & $2.95 \mathrm{n}$ & $47.9 \mathrm{a}$ & $47.9 \mathrm{a}$ & $47.9 \mathrm{a}$ \\
\hline & \multicolumn{6}{|c|}{ Soaking in excessive amount of water (v/v) $1: 3$ (M1) } \\
\hline 30.0 & 3.441 & $3.95 \mathrm{~h}$ & $3.63 \mathrm{k}$ & $32.9 \mathrm{~d}$ & $26.9 \mathrm{i}$ & $31.9 \mathrm{e}$ \\
\hline 37.5 & $4.10 \mathrm{~g}$ & $4.74 \mathrm{~b}$ & $4.21 \mathrm{f}$ & 23.51 & $18.7 \mathrm{~g}$ & 23.51 \\
\hline \multirow[t]{2}{*}{40.0} & $3.95 \mathrm{~h}$ & $\mathrm{G}^{*}$ & G & $27.1 \mathrm{~h}$ & $\mathrm{G}$ & $\mathrm{G}$ \\
\hline & \multicolumn{6}{|c|}{ Soaking in limited amounts of water (M2) } \\
\hline 30.0 & 3.541 & $4.32 \mathrm{e}$ & $3.81 \mathrm{ij}$ & $31.8 \mathrm{e}$ & 24.11 & $29.8 \mathrm{f}$ \\
\hline 37.5 & 4.26 ef & $4.91 \mathrm{a}$ & $4.43 \mathrm{~d}$ & $22.9 \mathrm{~m}$ & $16.8 \mathrm{q}$ & $21.6 \mathrm{n}$ \\
\hline \multirow[t]{2}{*}{40.0} & $4.10 \mathrm{~g}$ & G & G & $26.2 \mathrm{j}$ & $\mathrm{G}$ & $\mathrm{G}$ \\
\hline & \multicolumn{6}{|c|}{ Matriconditioning (M3) } \\
\hline 30.0 & $3.31 \mathrm{~m}$ & $3.76 \mathrm{j}$ & 3.451 & $35.9 \mathrm{~b}$ & $28.5 \mathrm{~g}$ & $32.2 \mathrm{c}$ \\
\hline 35.0 & $3.96 \mathrm{c}$ & $4.66 \mathrm{c}$ & $4.09 \mathrm{~g}$ & $25.4 \mathrm{k}$ & $20.3 \mathrm{o}$ & $25.3 \mathrm{k}$ \\
\hline 40.0 & $3.84 \mathrm{i}$ & G & G & $27.1 \mathrm{~h}$ & G & G \\
\hline
\end{tabular}

Means with the same letters for each trait are not significantly different at $\mathrm{p}<0.05$ according to the Duncan's multiple range test

* Seeds germinated already during incubation

\section{Correlation analyses}

Highly negative correlations were obtained between MGT and the variables characterising physiological-biochemical state of primed seeds, such as activity of catalase $\left(\mathrm{r}=-0.970^{* * *}\right)$, activity of total dehydrogenase $\left(\mathrm{r}=-0.962^{* * *}\right)$ and activity of cell cycle $\left(r=-0.974^{* * *}\right)$, but highly positive correlations between MGT and EL $\left(\mathrm{r}=0.951^{* * *}\right)$ or MGT and $\mathrm{T}_{75-25}\left(\mathrm{r}=0.892^{* * *}\right)$ (Table 4). The same relations, both positive and negative, were found between $\mathrm{T}_{75-25}$ and all the evaluated physiological-biochemical markers. The negatively significant correlations were determined between $\mathrm{T}_{75-25}$ and activity of catalase $\left(\mathrm{r}=-0.927^{* * *}\right)$, activity of total dehydrogenase $\left(\mathrm{r}=-0.874^{* * *}\right)$ and activity of cell cycle $\left(\mathrm{r}=-0.858^{* * *}\right)$. The significantly positive correlations were observed between $\mathrm{T}_{75-25}$ and $\mathrm{EL}$ $\left(r=0.808^{* * *}\right)$. In contrast, the correlation coefficients established between germination percentage (GP) and all the estimated variables were very low. The analysed correlations between MGT and $\mathrm{T}_{75-25}$ (Fig. 1) or MGT/T $\mathrm{T}_{75-25}$ and physiological-biochemical traits in relationship with the applied methods of conditioning (Fig. 2 \& 5), moisture content (Fig. 3 \& 6) and times of incubation (Fig. 4 \& 7) also proved to be very significant. 
Table 4. The correlation coefficients (r) between China aster seed sowing value viz. germination percentage (GP), mean germination time (MGT), time between 25 and $75 \%$ germination of $\mathrm{G}_{\max }\left(\mathrm{T}_{75-25}\right)$ and physiological events viz. total activity of dehydrogenase (TAD), activity of catalase (AC), activity of cell cycle (ACC) and electrolyte leakage (EL). The results have been expressed as the means for analyzed methods of conditioning, i.e. soaking in excessive amount of water (M1), soaking in limited amount of water (M2) or matriconditioning (M3); moisture content (30.0, 37.5 and 40.0\%) and time of incubation $\left(1,8\right.$ and 10 days at $\left.20^{\circ} \mathrm{C}\right)$

\begin{tabular}{|c|c|c|c|c|c|c|}
\hline & GP & MGT & $\mathrm{T}_{75-25}$ & TAD & $\mathrm{AC}$ & EL \\
\hline MGT & $-0.220^{* *}$ & & & & & \\
\hline $\mathrm{T}_{75-25}$ & $-0.389^{* *}$ & $0.892^{* * *}$ & & & & \\
\hline TAD & $0.164^{*}$ & $-0.962^{* * *}$ & $-0.874^{* * *}$ & & & \\
\hline $\mathrm{AC}$ & $0.222^{*}$ & $-0.970^{* * *}$ & $-0.927^{* * *}$ & $0.980^{* * *}$ & & \\
\hline EL & $-0.146^{*}$ & $0.951^{* * *}$ & $0.808^{* * *}$ & $-0.977^{* * *}$ & $-0.957^{* * *}$ & \\
\hline ACC & $0.154^{*}$ & $-0.974^{* * * *}$ & $-0.858^{* * * *}$ & $0.981^{* * *}$ & $0.971^{* * *}$ & $-0.979^{* * * *}$ \\
\hline
\end{tabular}

${ }^{* * *} ;{ }^{* *} ;{ }^{*}$ : significant at $\mathrm{p}<0.001 ; 0,01 ; 0,05$ probability levels respectively; $\mathrm{n}=64$
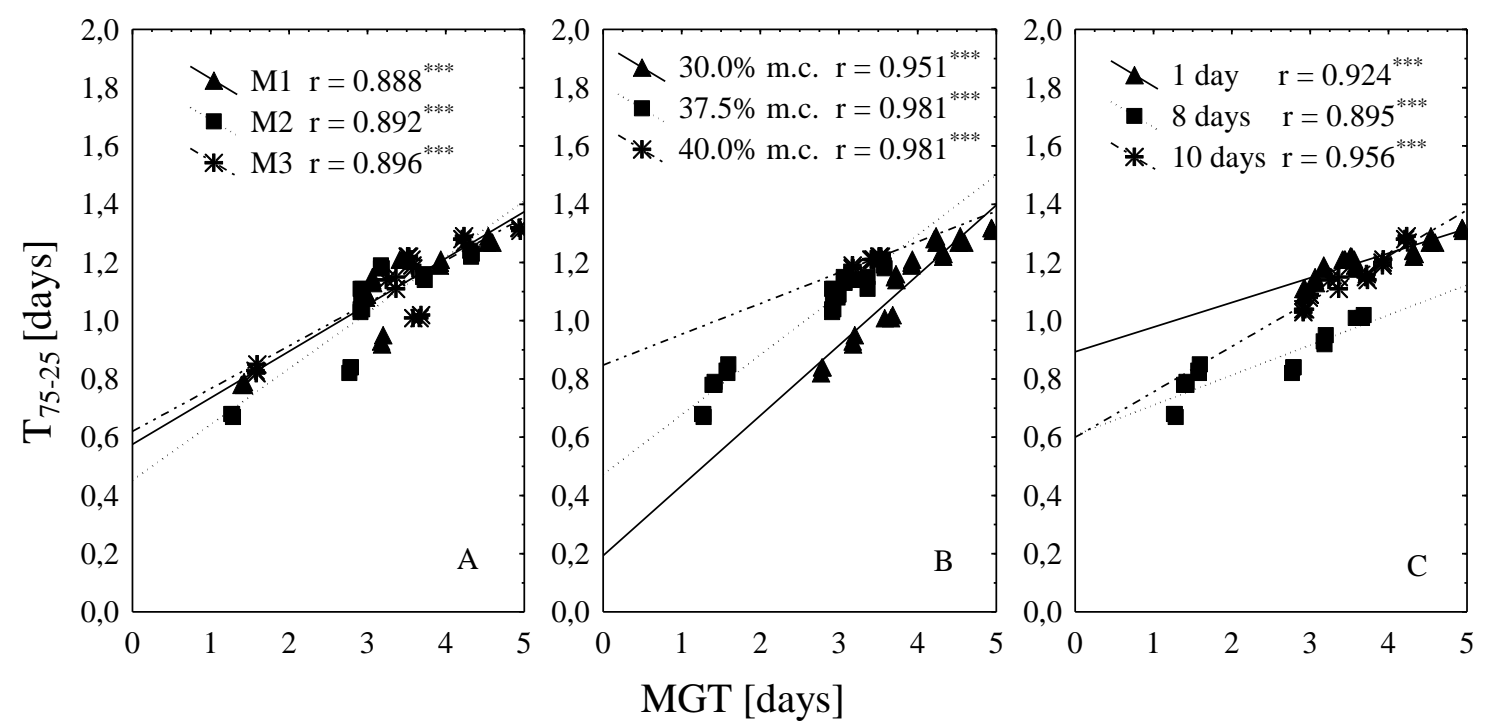

Fig. 1. Linear regressions between germination uniformity $\left(\mathrm{T}_{75-25}\right)$ and mean germination time (MGT) conditioned China aster seeds in relationship to applied: (A) - methods of conditioning (soaking in excessive amount of water (M1), soaking in limited amount of water (M2) or matriconditioning (M3); (B) - moisture content (m.c.) (30.0, 37.5 and $40.0 \%)$ and (C) - time of incubation (1, 8 and 10 days at $20{ }^{\circ} \mathrm{C}$ ) 

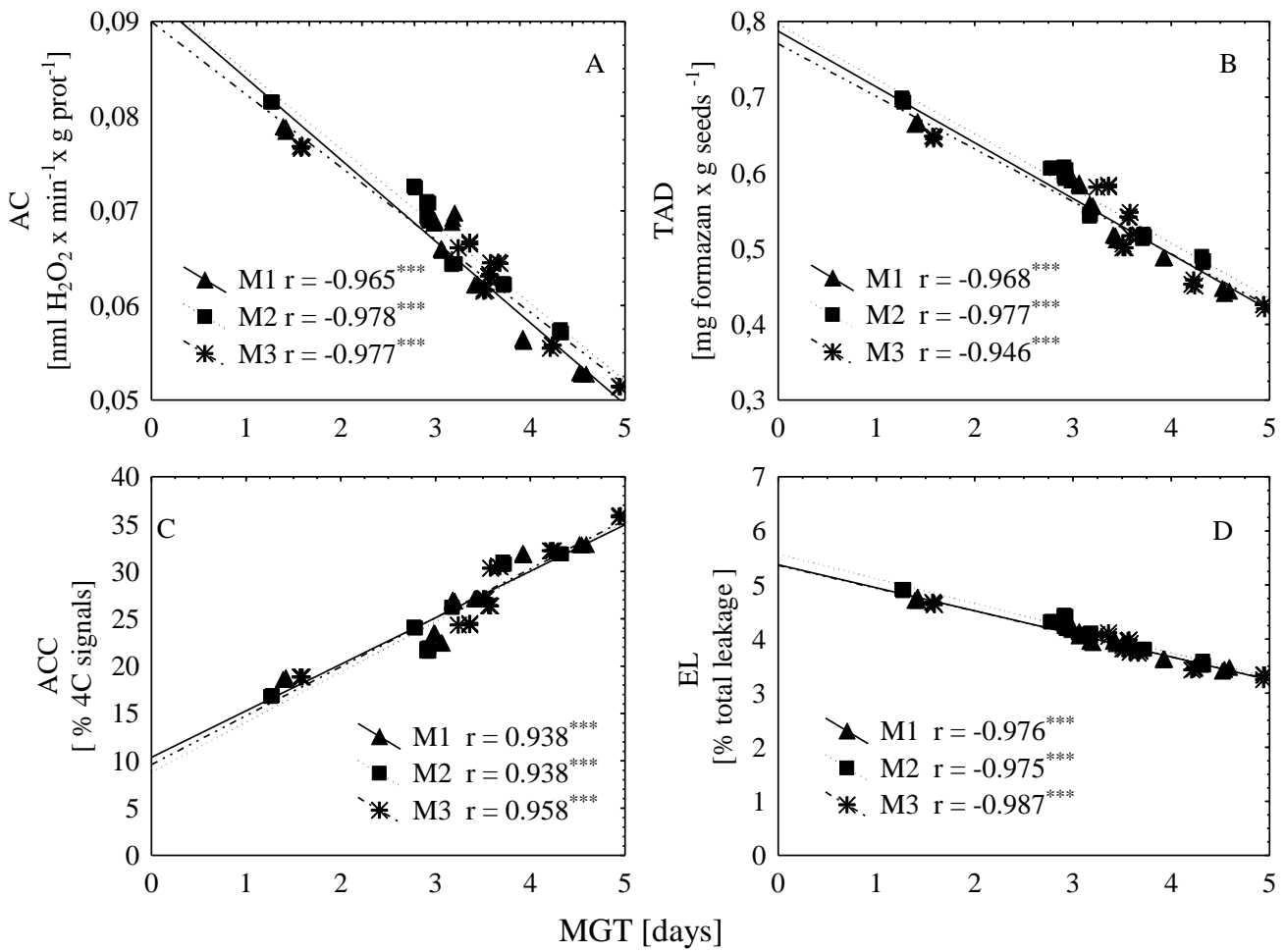

Fig. 2. Linear regressions between physiological and biochemical parameters (A) activity of catalase - AC, (B) total activity of dehydrogenases - TAD, (C) activity of cell cycle - ACC, and (D) electrolyte leakage - EC and mean germination time (MGT) of conditioned China aster seeds in relationship to applied methods of conditioning (soaking in excessive amount of water (M1), soaking in limited amount of water (M2) or matriconditioning (M3)
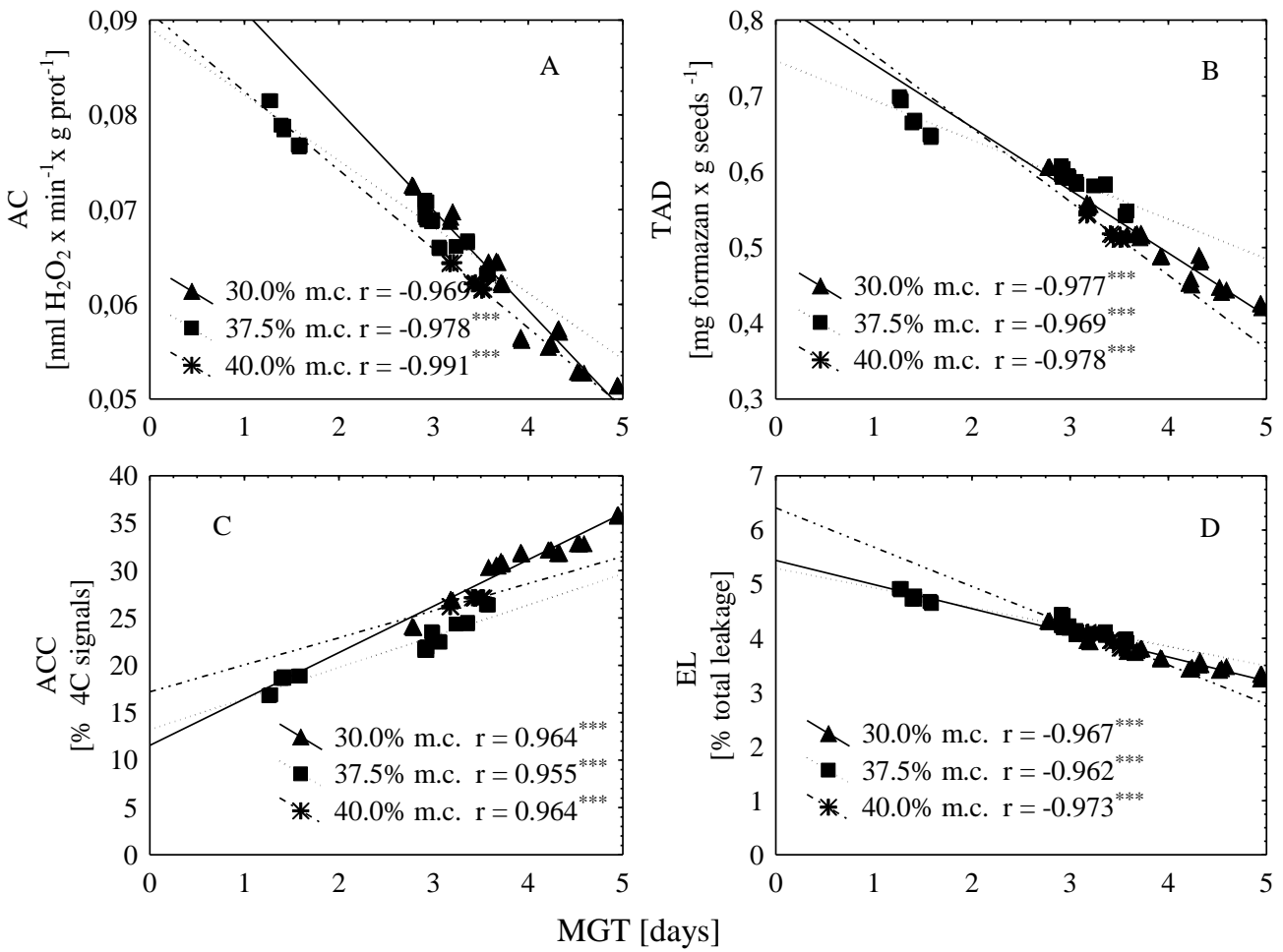

Fig. 3. Linear regressions between physiological and biochemical parameters (A) activity of catalase - AC, (B) total activity of dehydrogenases - TAD, (C) activity of cell cycle - ACC, and (D) electrolyte leakage - EC and mean germination time (MGT) of conditioned China aster seeds in relationship to applied time of incubation (1, 8 and 10 days at $20^{\circ} \mathrm{C}$ ) 

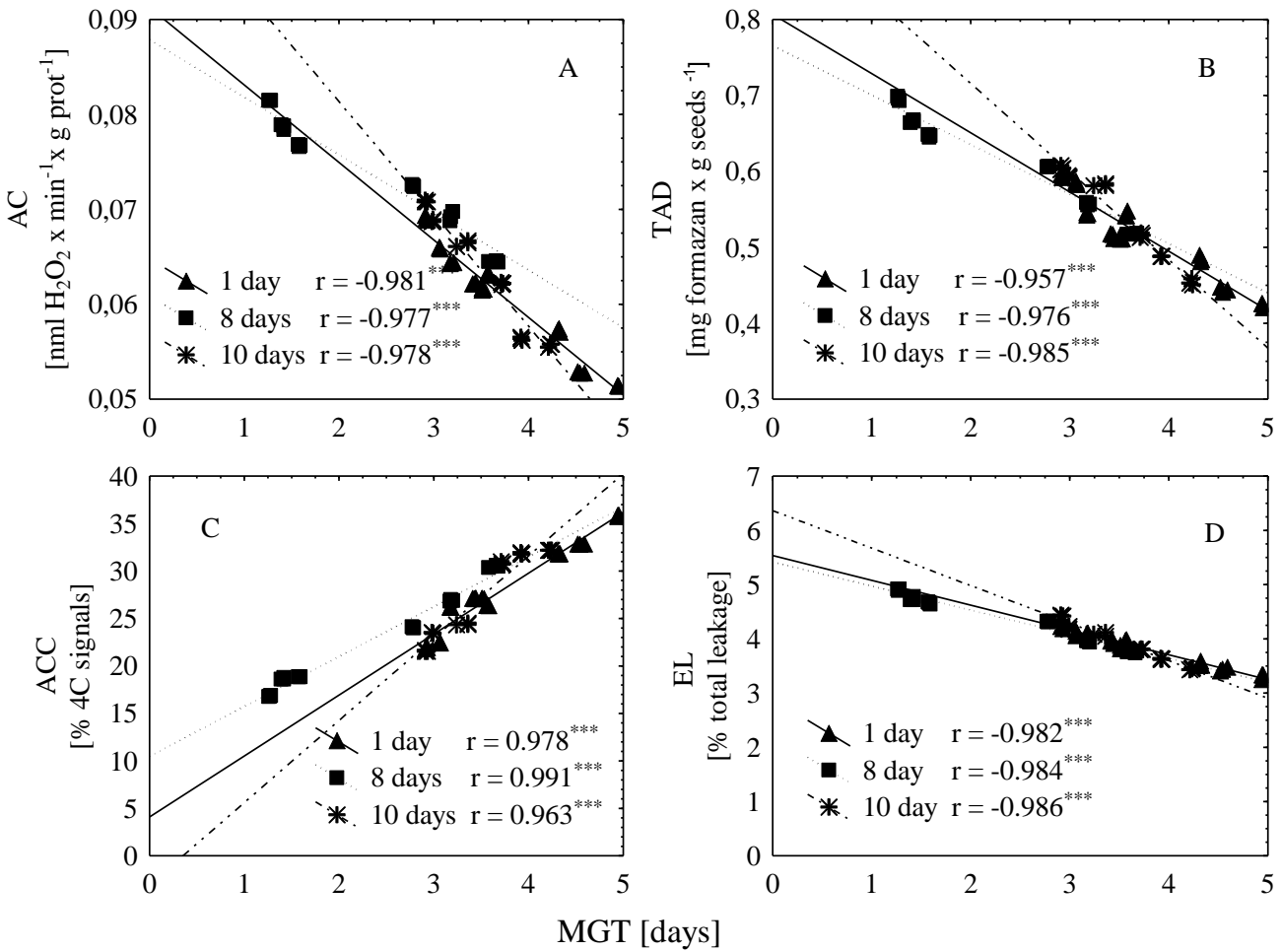

Fig. 4. Linear regressions between physiological and biochemical parameters (A) activity of catalase - AC, (B) total activity of dehydrogenases - TAD, (C) activity of cell cycle - ACC, and (D) electrolyte leakage - EC and mean germination time (MGT) of conditioned China aster seeds in relationship to applied moisture content (m.c.) (30.0, 37.5 and $40.0 \%$ )
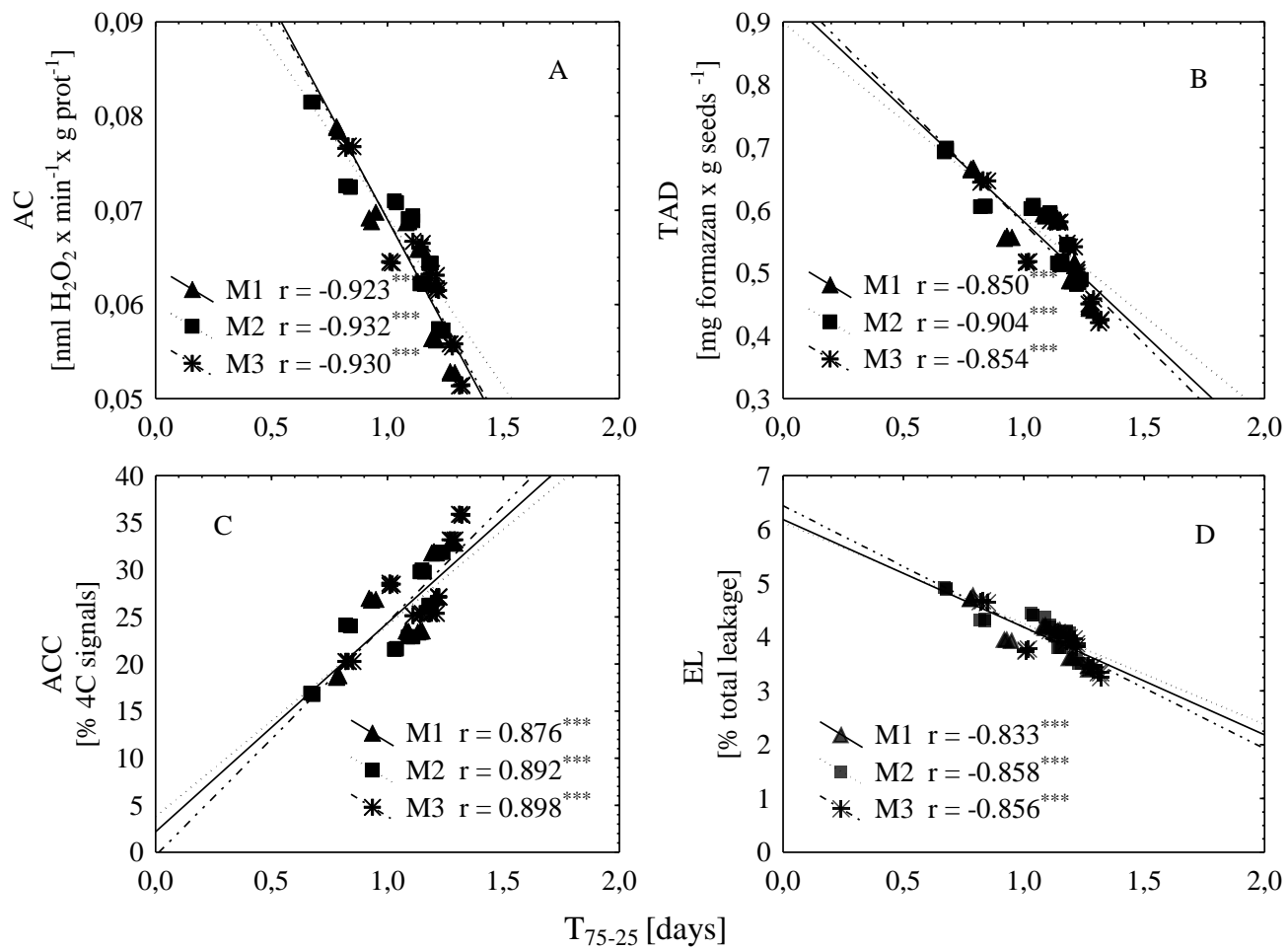

Fig. 5. Linear regressions between physiological and biochemical parameters (A) activity of catalase - AC, (B) total activity of dehydrogenases - TAD, (C) activity of cell cycle - ACC, and (D) electrolyte leakage - EC and germination uniformity $\left(\mathrm{T}_{75-25}\right)$ of conditioned China aster seeds in relationship to applied methods of conditioning (soaking in excessive amount of water (M1), soaking in limited amount of water (M2) or matriconditioning (M3) 

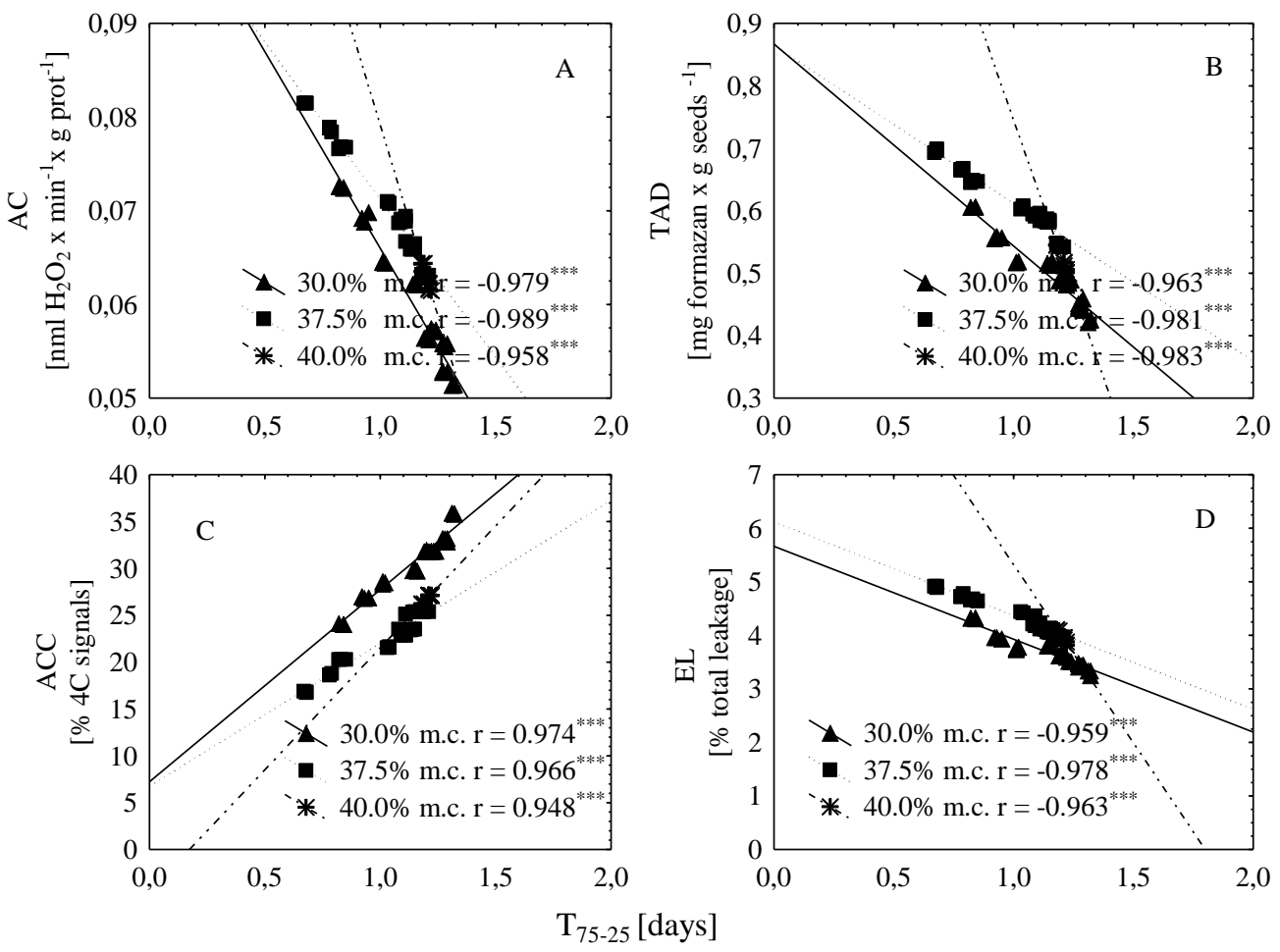

Fig. 6. Linear regressions between physiological and biochemical parameters (A) activity of catalase - AC, (B) total activity of dehydrogenases - TAD, (C) activity of cell cycle - ACC, and (D) electrolyte leakage - EC and germination uniformity $\left(\mathrm{T}_{75-25}\right)$ of conditioned China aster seeds in relationship to applied time of incubation (1, 8 and 10 days at $20^{\circ} \mathrm{C}$ )
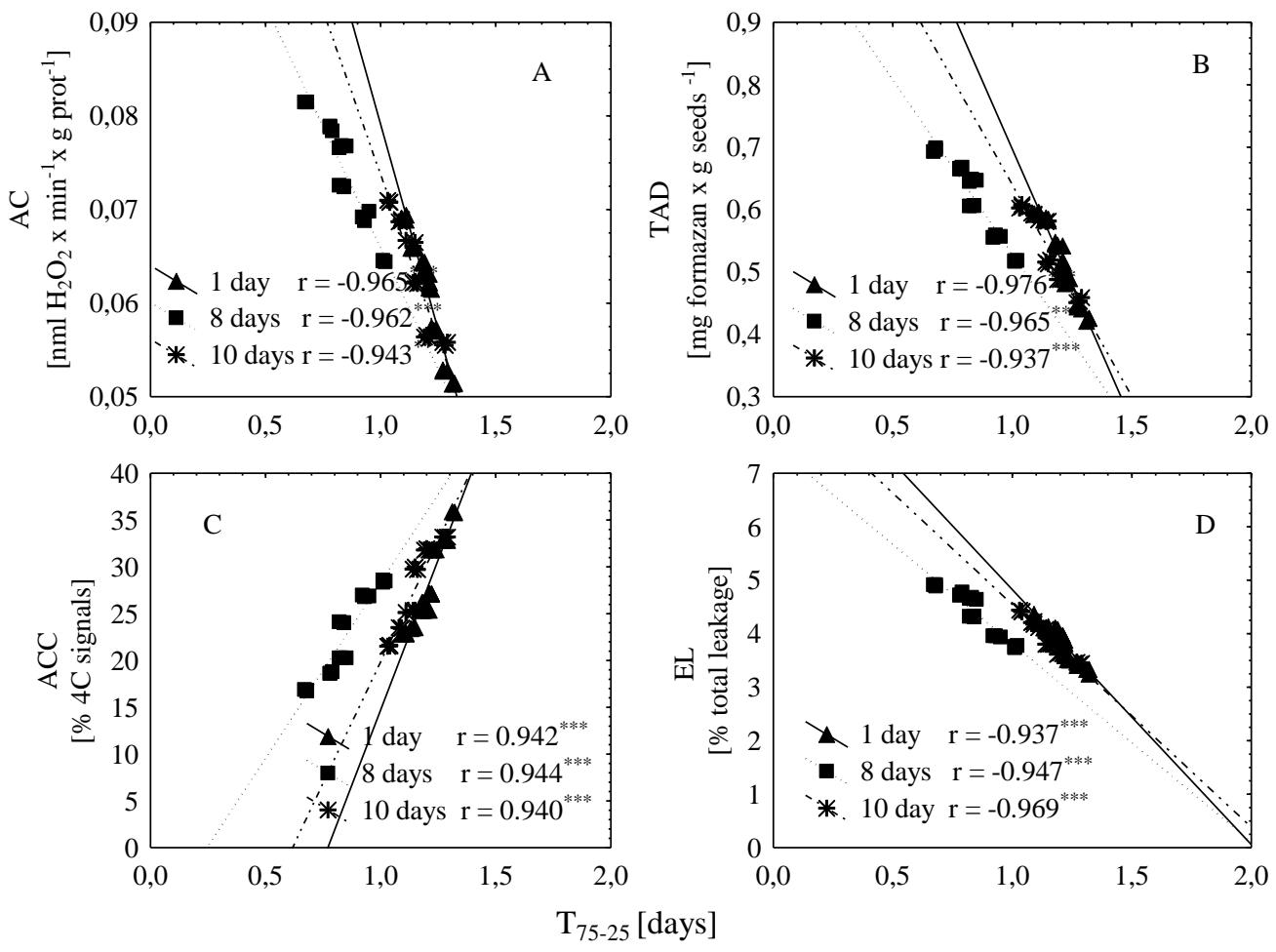

Fig. 7. Linear regressions between physiological and biochemical parameters (A) activity of catalase - AC, (B) total activity of dehydrogenases - TAD, (C) activity of cell cycle - ACC, and (D) electrolyte leakage - EC and germination uniformity $\left(\mathrm{T}_{75-25}\right)$ of conditioned China aster seeds in relationship to applied moisture content (m.c.) $(30.0,37.5$ and $40.0 \%)$ 


\section{DISCUSSION}

During the last decades, the seed industry faced tremendous changes in terms of technology, markets and regulations. However, new developments and improvements of commonly applied methods of refining seed germination of different plant species, including ornamental plants, are necessary. Seed priming (conditioning) is adopted by horticulturists as a safe, easy and an effective way to improve the quality of seeds. In our study, all kinds of priming significantly improved the ability of seeds to germinate. The positive impact, irrespective of the priming kind, appears stronger for MGT and $\mathrm{T}_{75-25}$ than for GP. Also Amooaghaie et al. (2010) did not find significant differences in the number of germinated tomato seeds in the effect of priming. The beneficial impact of seed conditioning on the GP should be important in case of seeds with lower initial ability to germinate.

The analyses of the selected parameters of China aster seed germination showed in the present study that MGT and $\mathrm{T}_{75-25}$ (uniformity) can be used as a possible quick and reliable test to rank a seed's quality. Correlations between MGT and uniformity of seeds were also found by Demir and Mavi (2008) in cucumber, and by Matthews et al. (2011) and Khajeh-Hosseini et al. (2009) in maize. Based on these data, it is possible to establish the optimal conditions for seed priming, as it was also shown in our earlier study (Badek et al. 2006, 2007). The results obtained indicate that hydration up to moisture content of $37.5 \%$ and subsequent incubation for 8 days was the most profitable for priming of China aster seeds contrary to extended priming duration (10 days) or higher moisture content of seeds (40\%) that had the negative impact on the seed germination or initiated the seed germination already at the end of their incubation periods. The acceleration in germination of primed seeds was caused by earlier beginning of the induction of biochemical changes in embryos leading to initiation of the germination processes, as dormancy breaking, imbibitions and activation of catalase, peroxidase, superoxide dismutase or changes in soluble sugar content and reduction of malondialdehyde accumulation that undergo at a salt stress condition in seedlings of sun- flower (Bailly et al. 2002), alfalfa (Hu et al. 2006), tomato (Afzal et al. 2009) and Pinus bungeana (Guo et al. 2012). Studies of Bailly et al. (1996, 2002), Badek et al (2006, 2007), Grzesik and Romanowska-Duda $(2009,2014)$ and Śliwińska (2009) proved that the evaluation of the activity level of catalase, dehydrogenases and cell cycle as well as the amount of the electrolyte leakage from seeds can be useful for indicating characterisation of embryo physiological activity in germinated seeds. The obtained results for China aster seeds showed not only close relationships between MGT and $\mathrm{T}_{75-25}$, but also high correlations between the changing germination parameters and the studied physiological events, caused by seed conditioning. The correlations between MGT/ $\mathrm{T}_{75-25}$ and variables characterising the physiological or biochemical state of the processes associated with seed germination were significant at $p<0.001$. Also, linear regression determining correlations for MGT and $\mathrm{T}_{75-25}$ can be useful for assessing the sowing value of China aster seeds.

High correlation between the physiological activities and the MGT or $\mathrm{T}_{75-25}$ and its alignment, indicates the possibility of using these characteristics as markers of the biological seed quality. The presented results showed a high negative correlation between activity of catalase and MTG and $\mathrm{T}_{75-25}$ of primed China aster seeds. Seed priming improved the antioxidant enzymes activity, which in turn reduces the adverse effects of reactive oxygen species (ROS). The increase in the catalase activity during priming was observed in our research and also in Bailly et al. (2000, 2004); El-Araby and Hegazi (2004); Lei et al. (2005), Ventura (2012) as well as Chen and Arora (2013). Different levels of enzyme activity should to be considered as a possible source of molecular markers.

The values of MGT and $\mathrm{T}_{75-25}$ were negatively correlated with TAD in China aster seeds. According to Kępczyńska et al. (2003), total dehydrogenase activity was higher in conditioned onion seeds in comparison with the untreated ones. In turn, the increased activity of dehydrogenase can be connected with higher intensity of the processes of seed respiration in course of incubation and can be used as the indicator of determining the germination and 
vigour of seeds (Grzesik et al. 2000). The total activity of dehydrogenase can be recommended as a useful marker of rapid germinability of primed China aster seeds.

In this study, a positive correlation was found between the studied germination parameters and the induction of DNA replication, represented by the presence of $4 \mathrm{C}$ cell nuclei. These results are in agreement with Śliwińska et al. (2009), Onwimol et al. (2012) and Chen and Arora's (2013) results and suggest that the cell cycle activity in seeds could be a marker to detect both seed maturity and progression of the germination process. The uniform and faster germination of seeds can be attributed to the enhanced synthesis of DNA during priming (Bray et al. 1989). Rewers et al. (2009) indicated that the pattern of G2/G1 ratio can be used as a marker of advancement in seed germination of several polysomatic species, including the cucumber. Flow cytometric data published by Varier et al. (2010) reveal that the improvement of germination associated with priming is accompanied by increase in $4 \mathrm{C}$ nuclear DNA. This indicates that priming enhances DNA replication allowing the advancement of the cell cycle from $\mathrm{G} 1$ to $\mathrm{G} 2$ phase.

High correlations between MGT/T $75-25$ and EL values found in this study suggest that conductivity readings may also be applied as a routine marker in indicating the seed germination ability. The seeds hydration up to $37.5 \%$ m.c. and their following incubation for 8 days caused minimal electrical conductivity, as compared with all other treatments. These findings agree with Powell (1986), Amooaghaie et al. (2010) and Farooq et al. (2011) studies, indicating that during the hydration process, membranes reorganise themselves to attain the original structure, disturbed while drying or because of the rapid entering of water into cells during the initial period of seed soaking. Priming of seeds results in a higher integrity of membranes, as the electrical conductivity of primed seeds decreased in comparison with the control group. Our results, similar to Matthews and Powell (2006), Khajeh-Hosseini and Rezazadeh (2011) and Demir et al. (2012) studies, recommend EL as the best, quick, rapid, cheap and simple method for testing seed quality on farms prior to sowing, using a portable conductivity meter.
The results obtained in this study confirmed that the physiological status of primed seeds can constitute the basis for evaluation of the progress in seed germination. Our data showed that the physiological traits through total activity of dehydrogenases and catalase, activity of cell cycle and electrolyte leakage were highly correlated with a mean germination time and uniformity of conditioned seeds. Such high correlations indicate the possibility of using of these traits as markers of biological quality of primed China aster seeds for prediction of their germinability. Most of the above discussed markers can be used in a laboratory condition, but the electrolyte leakage assessment may also be used by horticulturists as the routine, cheap and simple test in checking germination quality of seeds.

\section{Acknowledgements}

The Authors wish to kindly thank Prof. Elwira Śliwińska for her assistance and help in evaluation of cellular cycle activity.

\section{REFERENCES}

Afzal I.F., Munir C.M., Ayub S.M.A., Basra A., Hameed A., Nawaz A. 2009. Changes in antioxidant enzymes, germination capacity and vigour of tomato seeds in response of priming with polyamines. Seed Sci. Technol. 37: 765-770.

Amooaghaie R., Nikzad K., Shareghi B. 2010. The effect of priming on emergence and biochemical changes of tomato seeds under suboptimal temperatures. Seed Sci. Technol. 38: 508-512.

Badek B., van Duijn B., Grzesik M. 2006. Effects of water supply methods and seed moisture content on germination of China aster (Callistephus chinensis) and tomato (Lycopersicon esculentum Mill.) seeds. Eur. J. Agron. 24:.45-51. DOI: 10.1016/j.eja.2005.04.004.

Badek B., van Duijn B., Grzesik M. 2007. Effects of water supply methods and incubation on germination of China aster (Callistephus chinensis) seeds. Seed Sci. Technol. 35: 569-576.

Bailly C., Benamar A., Corbineau F., Côme D. 1996. Changes in malondialdehyde content and in superoxide dismutase, catalase and glutathione reductase activities in sunflower seeds as related to deterioration during accelerated ageing. Physiol. Plant. 97: 104-110. DOI: 10.1111/j.13993054.1996.tb00485. 
Bailly C., Benamar A., Corbineau F., Côme D. 2000. Antioxidant systems in sunflower (Helianthus annuus L.) seeds as affected by priming. Seed Sci. Res. 10: 35-42. DOI: 10.1017/S096025800000040.

Bailly C., Bogatek-Leszczynska R., Côme D., Corbineau F. 2002. Changes in activities of antioxidant enzymes and lipoxygenase during growth of sunfower seedlings from seeds of different vigour. Seed Sci. Res. 12: 47-55. DOI: 10.1079/SSR200197.

Bailly C., Leymarie J., Lehner A., Rousseau S., Côme D., Corbineau F. 2004. Catalase activity and expression in developing sunflower seeds as related to drying. J. Exp. Bot. 55: 475-483. DOI: 10.1093/jxb/erh050.

Bakht J., Shafi M., Shah R., Raziuddin., I. Munir 2011. Response of maize cultivars to various priming sources. Pak. J. Bot. 43(1): 205-212.

Bewley J.D., Black M. 1994. Seeds. Physiology of development and germination ( $2^{\text {nd }}$ edition). New York, Plenum Press.

Bray C.M., Davison P.A., Ashraf M., Taylor R.M. 1989. Biochemical changes during priming of leek seeds. Ann. Bot. 63: 185-193.

Capron I., Corbineau F., Dacher F., Job C., Côme D., Job D. 2000. Sugarbeet seed priming: effects of priming conditions on germination, solubilization of 11-S globulin and accumulation of LEA proteins. Seed Sci. Res. 10: 243-254. DOI: 10.1017/S0960258500000271.

de Castro R.D., Zheng X.Y., Bergervoet J.H.W., de Vos C.H.R., Bino R.J. 1995. ß-tubulin accumulation and DNA replication in imbibing tomato seeds. Plant Physiol. 109: 499-504. DOI: 10.1104/pp.109.2.499.

Chen K., Arora R. 2013. Priming memory invokes seed stress-tolerance. Environ. Exp. Bot. 94: 33-45. DOI: 10.1016/j.envexpbot.2012.03.005.

Demir I., Mavi K. 2008. Seed vigour evaluation of cucumber (Cucumis sativus L.) seeds in relation to seedling emergence. Res. J. Seed Sci. 1: 19-25. DOI: 10.3923/rjss.2008.19.25.

Demir I., Cebeci C., Guloksuz T. 2012. Electrical conductivity measurement to predict germination of commercially available radish seed lots. Seed Sci. Technol. 40: 229-237.

Dursun A., Ekinci M. 2010. Effects of different priming treatments and priming durations on germination percentage of parsley (Petroselinum crispum L.) seeds. Agr. Sci. 1(01): 17-53. DOI: 10.4236/as.2010.11003.

El-Araby M.M., Hegazi A.Z. 2004. Responses of tomato seeds to hydro- and osmo-priming, and possible relat- ions of some antioxidant enzymes and endogenous polyamine fractions. Egyptian J. Biol. 6: 81-93.

Farooq M., Aziz T., ur Rehman H., ur Rehman A., Cheema S.A., Aziz T. 2011. Evaluating surface drying and re-drying for wheat seed priming with polyamines: effects on emergence, early seedling growth and starch metabolizm. Acta Physiol. Plant. 33: 1707-1713. DOI: 10.1007/s11738-010-0707-3.

Gallardo K., Job C., Groot S.P.C., Puype M., Demol H., Vandekerckhove J., Job D. 2001. Proteomic analysis of Arabidopsis seed germination and priming. Plant Physiol. 126: 835-848. DOI: 10.1104/pp.126.2.835.

Górnik K., Grzesik M. 2002. Effect of Asahi SL on China aster 'Aleksandra' seed yield, germination and some metabolic events. Acta Physiol. Plant. 24: 379-383.

Grzesik M., Szafirowska A., Sokołowska A. 2000. Cytological and physiological effects of matriconditioning on cucumber seeds germination. Acta Hort. 517: 113-120.

Grzesik M., Romanowska-Duda Z.B. 2009. The effect of potential climatic changes, Cyanobacteria, Biojodis and Asahi SL on development of the Virginia fanpetals (Sida hermaphrodita) plants. Pamiętnik Puławski 151: 483-491.

Grzesik M., Romanowska-Duda Z.B. 2014. Biotechnological potential of algae and Cyanobacteria in improving germination, growth and metabolic activity of corn plants by grain conditioning and root application. Pol. J. Environ. Stud. 23: 1147-1153.

Guo S.J., Wang Y.C., Wang W.S. 2012. Effects of priming treatments on germination and biochemical characteristics of Pinus bungeana seeds. For. Stud. China. 14(3): 200-204. DOI: 10.1007/s11632-012-0302-3.

Hu J., Xie X.J., Wang Z.F., Song W.J. 2006. Sand priming improves alfalfa germination under high salt concentration stress. Seed Sci. Technol. 34: 199-204.

ISTA 2011. International Rules for Seed Testing. Seed Sci. Technol. 39.

Job C., Kersulec A., Ravasio L., Chareyre S., Pepin R., Job D. 1997. The solubilization of the basic subunit of sugarbeet seed 11-S globulin during priming. Seed Sci. Res. 7: 225-243. DOI: 10.1017/S0960258500003585.

Job D., Capron I., Job C., Dacher F., Corbineau F., Côme D. 2000. Identification of germination-specific protein markers and their use in seed priming technology. In: Black M., Bradford K. J., Va'zquez-Ramos J. (Eds.), Seed Biology: Advances and Applications. CAB International. Wallingford, UK, pp. 449-459. 
Joosen R.V.L., Kodde J., Willems L.A.J., Ligterink W., Hilhorst H.W.M. 2010. Seed Testing International. ISTA News Bulletin 140: 4-8.

Kępczyńska E., Piękna-Grochala J., Kępczyński J. 2003. Effect of matriconditioning on onion seed germination, seedling emergence and associated physical and metabolic events. Plant Growth Regul. 41: 269278. DOI: 10.1023/B:GROW.0000007509.94430.

Khajeh-Hosseini M., Lomholt A., Matthews S. 2009. Mean germination time in the laboratory estimates the relative vigour and field performance of commercial lots of maize. Seed Sci. Technol. 37: 446-461.

Khajeh-Hosseini M., Rezazadeh M. 2011. The electrical conductivity of soak-water of chickpea seeds provides a quick test indicative of field emergence. Seed Sci. Technol. 39: 692-696.

Lei Y.B., Song S.Q., Fu J.R. 2005. Possible involvement of anti-oxidant enzymes in the cross-tolerance of the germination/growth of wheat seeds to salinity and heat stress. J. Integr. Plant Biol. 47: 1211-1219.

Matthews S., Powell A.A. 2006. Electrical conductivity vigour test: physiological basis and use. ISTA News Bulletin 131: 32-35.

Matthews S., Beltram E., El-kha dem R., Khaj eh-Hosseini M., Nasehza deh M., Urso G. 2011. Evidence that time for repair during early germination leads to vigour differences in maize. Seed Sci. Technol. 39: 501-509.

Nascimento W.M., Aragao F.A.S. 2004. Musk-melon seed priming in relation to seed vigor. Sci. Agr. 61(1): 114-117. DOI: 10.1590/S0103-90162004000100019.
Onwimol D., Chanprame S., Thongket T. 2012. Arrest of cell cycle associated with delayed radicle emergence in deteriorated cucumber seed. Seed Sci. Technol. 40: 238-247.

Powell A.A. 1986. Cell membranes and seed leachate conductivity in relation to the quality of seed for sowing. J. Seed Technol. 10: 81-99.

Rewers M., Sadowski J., Śliwińska E. 2009. Endoreduplication in cucumber (Cucumis sativus) seeds during development, after processing and storage, and during germination. Ann. Appl. Biol. 155: 431-438. DOI:10.1111/j.1744-7348.2009.00362.

Śliwińska E. 2008. Estimation of DNA content in plants using flow cytometry. In: Cytometry methods. PituchNoworolska A., Skierski J. (Eds.), Post. Biol. Kom. 24: 165-176.

Śliwińska E. 2009. Nuclear DNA replication and seed quality. Seed Sci. Res. 19: 15-25. DOI: 10.1017/S0960258508186275.

Taylor A.G, Churchill D.B., Lee S.S., Bisland D.M., Cooper T.M. 1993. Color sorting of coated brassica seeds by fluorescent sinapine leakage to improve germination. J. Amer. Soc. Hort. Sci. 118: 551-556.

Varier A., Vari A.K., Dadlani M. 2010. The sub-cellular basis of seed priming. Curr. Sci. 99: 450-456.

Ventura L., Donà M., Macovei A., Carbonera D., Buttafava A., Mondoni A., Rossi G., Balestrazzi A. 2012. Understanding the molecular pathways associated with seed vigor. Plant Physiol. Biochem. 60: 196-206. DOI: 10.1016/j.plaphy.2012.07.031.

Yu-jie L.J., Dorna H., Guo S.J., Zhai M. P. 2009. Effects of osmopriming and hydropriming on vigour and germination of China aster [Callistephus chinensis (L.) Nees.] seeds. For. Stud. China. 11(2): 111-117. DOI: 10.1007/s11632-009-0019-0. 